\title{
Amelioration of Auditory Response by DA9801 in Diabetic Mouse
}

\author{
Yeong Ro Lee, ${ }^{1,2}$ Bin Na Hong, ${ }^{2,3}$ You Ri Her, ${ }^{2}$ Rodrigo Castañeda, ${ }^{1,2}$ \\ Hyo Won Moon, ${ }^{2}$ and Tong Ho Kang ${ }^{1,2}$ \\ ${ }^{1}$ Graduate School of Biotechnology, Kyung Hee University, Global Campus, Gyeonggi 446-701, Republic of Korea \\ ${ }^{2}$ Department of Oriental Medicinal Materials \& Processing, College of Life Sciences, Kyung Hee University, Global Campus, \\ Gyeonggi 446-701, Republic of Korea \\ ${ }^{3}$ Department of Audiology, Nambu University, Gwangju 506-824, Republic of Korea
}

Correspondence should be addressed to Tong Ho Kang; panjae@khu.ac.kr

Received 5 January 2015; Revised 4 March 2015; Accepted 10 March 2015

Academic Editor: Shuang-En Chuang

Copyright (C) 2015 Yeong Ro Lee et al. This is an open access article distributed under the Creative Commons Attribution License, which permits unrestricted use, distribution, and reproduction in any medium, provided the original work is properly cited.

\begin{abstract}
Diabetes mellitus (DM) is a metabolic disease that involves disorders such as diabetic retinopathy, diabetic neuropathy, and diabetic hearing loss. Recently, neurotrophin has become a treatment target that has shown to be an attractive alternative in recovering auditory function altered by DM. The aim of this study was to evaluate the effect of DA9801, a mixture of Dioscorea nipponica and Dioscorea japonica extracts, in the auditory function damage produced in a STZ-induced diabetic model and to provide evidence of the mechanisms involved in enhancing these protective effects. We found a potential application of DA9801 on hearing impairment in the STZ-induced diabetic model, demonstrated by reducing the deterioration produced by DM in ABR threshold in response to clicks and normalizing wave I-IV latencies and Pa latencies in AMLR. We also show evidence that these effects might be elicited by inducing NGF related through Nr3cl and Akt. Therefore, this result suggests that the neuroprotective effects of DA9801 on the auditory damage produced by DM may be affected by NGF increase resulting from Nr3cl via Akt transformation.
\end{abstract}

\section{Introduction}

Diabetes mellitus (DM) is one of the most common metabolic diseases and is divided according to the mechanism in which the hyperglycemia is generated into two types, dysfunction in insulin secretion and resistance to its activity. This disruption in metabolism involves the development of many disorders in the entire organism, such as retinopathy, neuropathy, and nephropathy. Recently, evidence studies reported that hearing impairment could be caused by DM [1]. DM induces cochlear dysfunction by loss of outer hair cells (OHCs) and spiral ganglion neuron atrophy, degeneration of the cochlear lateral walls in the inner ear [2-7], because high glucose level may alter inner ear function by affecting the inner ear damage through sorbitol pathway involvement and accumulation of advanced glycation end products. Furthermore, the hyperglycemic state produced in DM has been related to hearing impairment in a short period disruption in auditory storage and slow speed of auditory information processing
[8-10]. These failures are accompanied by an enhanced rate of programmed cell death, or apoptosis in the auditory system. In addition, our previous study concluded that hearing impairment was found in the streptozotocin- (STZ-) induced diabetic mouse model, developing an impairment in the auditory pathway from the auditory nerve to the midbrain [11].

NGF is essential for viability, differentiation, and maintenance of nerve cells $[12,13]$. Also, it contributes to repair the nervous system $[14,15]$. NGF binds with two classes of receptors, a tyrosine kinase receptor (TrkA, TrkB, and TrkC) and a low-affinity receptor called $\mathrm{p} 75^{\mathrm{NTR}}[16-19]$. It has been proposed that when NGF binds with Trk, it became phosphorylated itself, serving as a binding site for specific signaling protein such as Akt through PI3 kinase [20-24], which binds and phosphorylates Bad, a member of the Bcl2 family [25-27], blocking the apoptosis pathway, resulting in increased cell viability. NGF has shown to be induced by glucocorticoid in vivo $[28,29]$. In addition, $\mathrm{Nr} 3 \mathrm{cl}$ is 
glucocorticoid receptor which controls transcription of target genes, and expression was found in PC12 cell, mouse, rat, and human auditory system, and previous study reported that glucocorticoid sensitivity might be dependent on expression level of $\mathrm{Nr3}$ cl [30-35].

Recently, pathogenetic control of diabetic neuropathy has been improved after neurotrophic therapy, such as NGF treatment, and by targeting pathological factors, in both STZinduced DM animal models and in the human condition $[36,37]$, which could be relevant to diabetic hearing impairment. In diabetic neuropathy, NGF levels are decreased in peripheral nerve such as superior cervical ganglion and sciatic nerve in STZ-induced rats $[38,39]$. It also may be involved in differentiation of acoustic ganglion cells and hair cells [40]. DA9801 has shown to induce endogenous NGF expression, supported by a recovery effect on the peripheral nerve in vitro and in vivo [41-44]. In our previous study of DA9801, a mixture of Dioscorea japonica and Dioscorea nipponica extracts showed a peripheral nerve protection effect in rats with STZ-induced diabetes through induction of endogenous NGF. In addition, other studies have confirmed the ameliorative effect of DA9801 on DPN in diabetic rats and even in a phase II clinical study, improving nerve conduction velocity and promoting recovery from neuronal degeneration [41-44]. The aim of the study was to evaluate the ameliorative effects produced by DA9801 on the auditory dysfunction produced in a STZ-induced diabetic model and to provide evidence of the possible mechanism of action in the auditory neural protection and survival related to induce endogenous NGF through $\mathrm{Nr} 3 \mathrm{cl}$.

\section{Materials \& Methods}

2.1. Animal. All of the experimental procedures were performed in accordance with the Principles of Laboratory Animal Care (NIH publication, \#80-23, revised 1996) and the Animal Care and Use Guidelines of Nambu University, Korea. Seven-week-old adult male ICR mice were obtained from Samtako Co. (Osan, Korea) with an average weight between 30 and $33 \mathrm{~g}$. The mice were maintained in a standard laboratory animal facility at $12 \mathrm{~h}$ light/12 h dark cycles with food and water ad libitum.

2.2. Diabetes Mellitus Induction. DM was induced by a single $120 \mathrm{mg} / \mathrm{kg}$ I.P. injection of STZ dissolved in $0.01 \mathrm{M}$ sodium citrate buffer ( $\mathrm{pH} 4.5)$. One week later, blood glucose measurements from nonfasting mice were taken from mouse tail pricks with strip-operated blood glucose sensors (ONETOUCH Ultra, Inverness Medical Ltd., UK). Diabetic mice with blood glucose levels $\geq 300 \mathrm{mg} / \mathrm{dL}$ were used in experiments.

2.3. Plant Material and Extract Preparation. Dried rhizomes of $D$. japonica and $D$. nipponica were mixed in a specific ratio $(3.5: 1)$ and extracted with $50 \%$ ethanol three times at room temperature for $48 \mathrm{~h}$. After filtration, the aqueous ethanol extract was evaporated under reduced pressure rotary vacuum evaporator with vacuum $\mathrm{MZ} 2 \mathrm{C} \mathrm{NT}+\mathrm{AK}+\mathrm{EK}$
(Vacuubrand, Korea). The extract was then lyophilized for a complete removal of the residual solvent to yield a brown powder. The contents of two marker components, dioscin $(1.37 \%)$ and allantoin (3.29\%), in DA9801 were evaluated by HPLC.

2.4. DA9801 Administration. Animals assigned to the evaluation of the auditory function and NGF levels were divided into 3 groups ( $n=10$ /group). Nondiabetic ICR mice (normal group) and nontreated STZ-induced diabetic mice (DM group) were treated orally once daily with $0.5 \mathrm{~mL}$ of distilled water, and treated STZ-induced diabetic mice (DM-DA) were treated orally with DA9801 $100 \mathrm{mg} / \mathrm{kg}$ once daily for 8 weeks.

Animals assigned to the evaluation of the mechanisms related to NGF were divided into 3 groups ( $n=5$ /group). Normal group mice were treated with $0.5 \mathrm{~mL}$ of distilled water and DA100 group and DA300 group mice were treated orally with $100 \mathrm{mg} / \mathrm{kg}$ and $300 \mathrm{mg} / \mathrm{kg}$ doses of DA9801.

2.5. Auditory Function Tests. To investigate the DA9801 effect on auditory impairment, hearing thresholds and latencies were measured in normal, DM, and DM-DA groups using auditory brainstem response (ABR) and auditory mid-latency response (AMLR). The auditory function tests were performed with the mice under anesthesia after an I.M. administration of xylazine $(0.43 \mathrm{mg} / \mathrm{kg})$ and ketamine $(4.57 \mathrm{mg} / \mathrm{kg})$. The rectal temperature was maintained at $37^{\circ} \mathrm{C} \pm 0.5^{\circ} \mathrm{C}$ using a heating lamp at the time of testing.

For the auditory electrophysiological tests, two-channel recordings (GSI Audera, Viasys Healthcare Inc., USA) were obtained through needle electrodes inserted subcutaneously at the vertex. Reference electrodes were placed below the pinna of the left and right ears, and a ground electrode was inserted into the shoulder. Electrode impedances were in the range of $2 \mathrm{k} \Omega$ to less than $5 \mathrm{k} \Omega$ for the electrode pairs.

For the ABR recordings, alternating clicks (0.1 ms duration) were delivered through earphones (Etymotic ER-3A) at a rate of 20.1 stimuli/s. Physiological filters were set to pass electrical activity between 100 and $3000 \mathrm{~Hz}$. Monaural responses were recorded for each mouse and averaged in a $10.24 \mathrm{~ms}$ time window. One thousand sweeps were collected. To determine the thresholds of ABR recordings, the clicks were reduced in $10 \mathrm{~dB}$ steps. When no response was detected, the level increased in $5 \mathrm{~dB}$ steps until a response was determined. ABR parameters were evaluated based on the hearing thresholds and interpeak latencies of waves I-IV at a peak sound pressure level (pSPL) of $90 \mathrm{~dB}$.

For the AMLR measurements, rarefaction clicks $(0.1 \mathrm{~ms}$ duration) were delivered through earphones at a rate of 9.1 stimuli/s. Filters were set to pass activity between 10 and $250 \mathrm{~Hz}$. An average of 250 sweeps was determined in a $70 \mathrm{~ms}$ time window. The parameters of AMLR were evaluated with absolute latencies of wave $\mathrm{Pa}$ at a pSPL of $90 \mathrm{~dB}$.

2.6. NGF Assays. In order to evaluate NGF level in peripheral nerve, after the final auditory function tests were taken 8 weeks after treatment, serum and sciatic nerves were 
TABle 1: Real-time PCR primer sequence.

\begin{tabular}{lllc}
\hline Gene & Stand & Sequence $\left(5^{\prime}-3^{\prime}\right)$ & Gene bank accession number \\
\hline \multirow{2}{*}{ Nr3cl (glucocorticoid receptor) } & Forward & GTG TGA GTC CTT AGT GAC GAG & \multirow{2}{*}{ NM_008173.3 } \\
& Reverse & AAG AAG GAG CAA AAT ACT GGG & \multirow{2}{*}{ NM_001033124.1 } \\
\hline \multirow{2}{*}{ TrkA (tyrosine kinase receptor) } & Forward & ACC CTT TTG AGT TCA ACC CTG & NCT CTT GAT GTG CTG TTA CCG \\
\hline Reverse & Forward & TGT ATG AAG GCT TTG GTC TCC & NM_007393.3 \\
& Reverse & GTC TCA AGT CAG TGT ACA GGC & \\
\hline
\end{tabular}

collected for NGF evaluation. Tissue samples were homogenized in NGF lysis buffer (Tris-HCl $100 \mathrm{mM}$, bovine serum albumin (BSA) 2\%, $\mathrm{NaCl} 1 \mathrm{M}$, EDTA-4Na $4 \mathrm{mM}$, Triton X$1002 \%$, sodium azide $0.1 \%, \mathrm{pH} 7.0$, and phenylmethylsulfonyl fluoride $17 \mu \mathrm{g} / \mathrm{mL}$ ) and centrifuged at $4^{\circ} \mathrm{C}$ and $14,000 \mathrm{rpm}$ during $20 \mathrm{~min}$. The supernatant was subjected to ELISA in 96-well plates as described elsewhere, following the manufacturer's instructions.

2.7. Total RNA Preparations. The nondiabetic ICR mice (normal) were treated once orally with $0.5 \mathrm{~mL}$ of distilled water with DA9801 at 100 and $300 \mathrm{mg} / \mathrm{kg}$ (DA100 and DA300). Liver tissues were collected after 2 hours of treatment. Total RNA was isolated from the liver using Trizol Reagent (Life science), following the manufacturer's instructions. $500 \mu \mathrm{L}$ of the Trizol reagent was added to tissue sample and was homogenized. In addition, $100 \mu \mathrm{L}$ of chloroform (Sigma) was added, and a vortex was used for $10-15 \mathrm{sec}$ and then centrifuged at $14,000 \mathrm{rpm}$ for $15 \mathrm{~min}$ at $4^{\circ} \mathrm{C}$. After taking the supernatant, the same amount of isopropanol (JUNSEI) was added. Total RNA was transferred into a pellet and washed with $75 \%$ EtOH in DEPC treated water (Sigma). The amount of RNA was measured by NanoDrop 2000 (Thermo scientific).

2.8. Quantitative Real-Time PCR. In order to evaluate $\mathrm{Nr} 3 \mathrm{cl}$ and TrkA mRNA expression level the following was done First, DNase I (Promega) was used in order to digest genomic DNA. cDNA was synthesized from $4 \mathrm{mg}$ of total RNA using the RevertAid First Strand cDNA Synthesis Kit (Thermo Scientific) and OligoDT primer, following the manufacturer's instructions. Each real-time PCR was carried out in triplicate in a total of $20 \mu \mathrm{L}$ reaction mixture in Rotor gene Q (Qiagen) using specific primer (Table 1). The housekeeping gene $\beta$ actin was concurrently amplified in each sample as a control and was used for normalization. The Ct (threshold cycle) values of target genes obtained from the liver samples from the DM and DA100 groups complemented line were normalized to the endogenous reference gene actin $\left(\Delta \mathrm{Ct}=\mathrm{Ct}_{\text {target }}-\right.$ $\left.\mathrm{Ct}_{\text {reference }}\right)$ and compared with those values obtained from the calibrator normal group $\left(\Delta \Delta \mathrm{Ct}=\Delta \mathrm{Ct}_{\text {sample }}-\Delta \mathrm{Ct}_{\text {calibrator }}\right)$ [45].

2.9. Protein Extraction. Frozen liver tissue extraction samples were prepared by homogenization in $500 \mu \mathrm{L}$ of iced extraction buffer (HEPES $20 \mathrm{mM}, \mathrm{KCl} 100 \mathrm{mM}$, glycerol 5\%, EDTA $5 \mathrm{mM}, \mathrm{MgCl}_{2} 1 \mathrm{mM}$, DTT $1 \mathrm{mM}$, and Triton X-100
$0.1 \%)$ with protease inhibitors (Roche) and then centrifuged at $14,000 \mathrm{rpm}$ at $4^{\circ} \mathrm{C}$ for $15 \mathrm{~min}$, and the supernatant was collected in a new tube. The amount of protein was measured by NanoDrop 2000 (Thermo scientific). Then the same amount of $2 X$ SDS-PAGE sample buffer (1 M Tris ( $\mathrm{pH} 6.8)$, $0.5 \mathrm{M}$ EDTA, 10\% SDS, 2-mercaptoethanol, 50\% glycerol, and bromophenol blue) was added to the extract of protein. The mixture was boiled at $95^{\circ} \mathrm{C}$ for $5 \mathrm{~min}$ and then kept at $-20^{\circ} \mathrm{C}$.

2.10. Western Blotting. The $40 \mu \mathrm{g}$ of total protein was loaded to the SDS-PAGE and subsequently transferred to nitrocellulose membrane. The membrane was blocked by $5 \%$ skim milk (Bio Basic Canada Inc.) or 5\% BSA (Roche) with TBS-T. After blocking, the membrane was probed with dilution of the anti-Nr3cl (Bethyl), anti-p-Akt (Cell Signaling), and anti- $\beta$ actin (Santa Cruz) primary antibody, followed by the addition of horseradish peroxidase- (HRP-) conjugated secondary antibody. Immunoreactive proteins were visualized using a WEST-One (iNtRON). Band intensities were determined using the ImageQuant LAS 4000 (GE Healthcare) and Quantity One software (Bio-Rad). $\beta$-actin was used as constitutive control for normalization.

2.11. Statistical Analysis. Data were analyzed using the Prism 5 Statistical Software package (GraphPad, San Diego, CA). All data are expressed as the mean \pm standard error mean (SEM) or $95 \%$ confidence interval (CI). Statistical comparisons between the groups were performed using one-way repeated measures ANOVA with Tukey's post hoc test. Values of $P<$ $0.05,0.01$, and 0.001 were considered statistically significant.

\section{Result}

3.1. Body Weight and Blood Glucose Level in Normal, DM, and DM-DA Groups. We measured body weights and blood glucose levels in normal, DM, and DM-DA groups. Mean body weight (BW) of normal mice was $30.75 \mathrm{~g}$ (95\% CI, 29.91-31.59) and blood glucose level (BGL) was $133.83 \mathrm{mg} / \mathrm{dL}$ (95\% CI, 129.98-137.68). However, BW of DM mice decreased to $26.71 \mathrm{~g}(95 \% \mathrm{CI}, 25.95-27.47)$ and BGL increased to more than $600 \mathrm{mg} / \mathrm{dL}$. Also, BW of the groups treated with DA9801 (DM-DA) showed decreased values compared to the normal group, ranging to $28.87 \mathrm{~g}$ (95\% CI, 26.58-31.16) with unchanged BGL (Table 2). Slightly increased values were shown compared to the DM group. Therefore, these results suggest that DA9801 has no effect on body weights and blood glucose levels. 


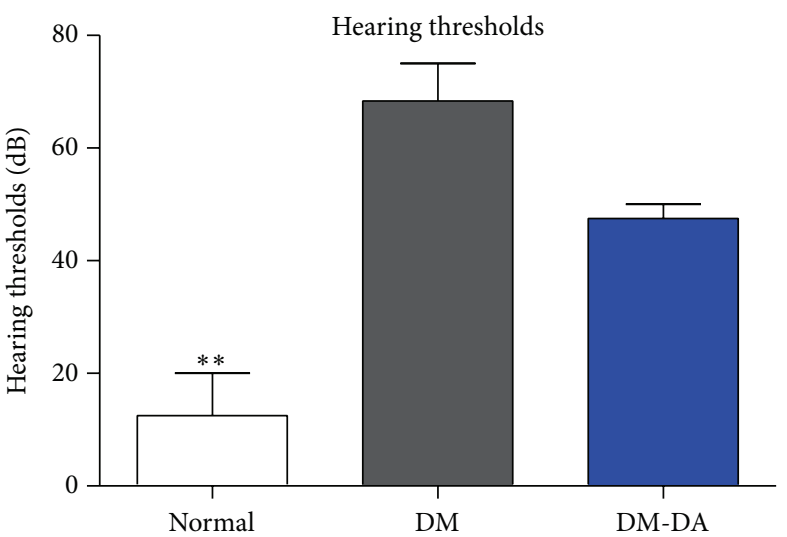

(a)

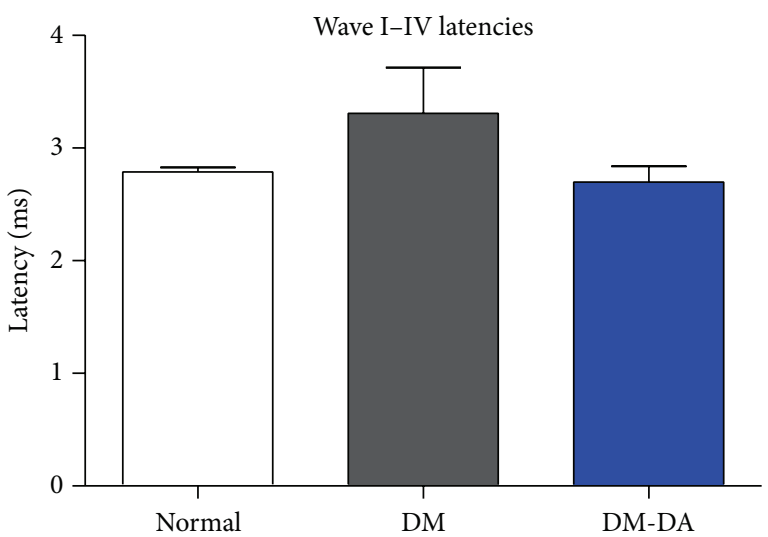

(b)

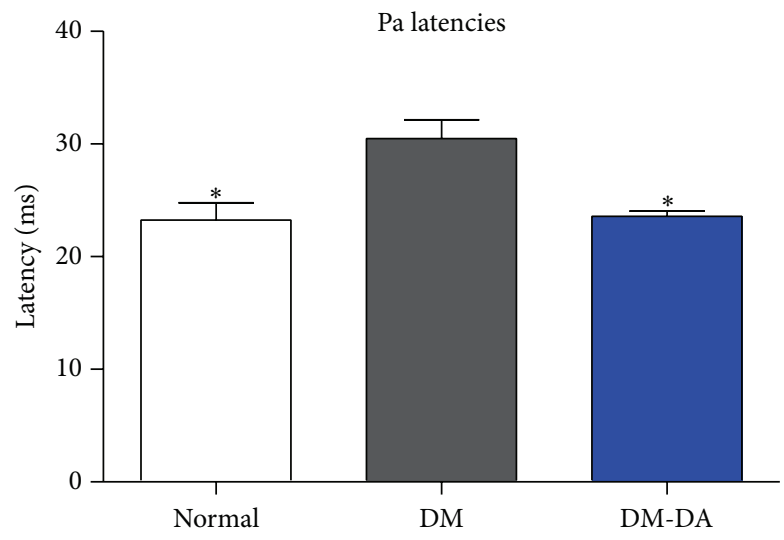

(c)

FIGURE 1: Hearing thresholds and wave latencies measured by auditory brainstem response (ABR) test, and Pa latencies measured by auditory middle-latency response (AMLR) in normal, DM, and DM-DA groups. (a) Hearing thresholds and (b) wave I-IV latencies by the click stimulus in ABR test of 3 groups. (c) Pa latencies by the click stimulus in AMLR test. ${ }^{*} P<0.05$ and ${ }^{* *} P<0.01$ indicate significant differences from DM group using one-way ANOVA.

TABLE 2: Body weights and blood glucose levels of normal, DM, and DM-DA groups.

\begin{tabular}{lcc}
\hline Groups & Body weight $(\mathrm{g})$ & Glucose levels $(\mathrm{mg} / \mathrm{dL})$ \\
\hline Normal & $30.75 \pm 1.35$ & $133.83 \pm 6.21$ \\
DM & $26.71 \pm 1.22$ & $\geq 600.00$ \\
DM-DA & $28.87 \pm 3.69$ & $\geq 600.00$ \\
\hline
\end{tabular}

Body weights and blood glucose levels at 8 weeks after DA9801 treatments in normal, DM, and DM-DA groups (normal: nondiabetic mice, DM: STZinduced diabetic mice model, and DM-DA: STZ-induced diabetic mice were treated with DA9801). The data shown indicate the means \pm SEM.

3.2. Effect of DA9801 on Auditory Function. The hearing thresholds in the DM group of the animals assigned to the evaluation of the auditory function show increased values after 8 weeks of treatment compared to normal group, from $12.5 \mathrm{~dB}$ (95\% CI, 7.85-17.15) to $68.33 \mathrm{~dB}$ (95\% CI, 64.2-72.46) (Figure 1(a)). However, hearing thresholds in the DM-DA group showed decreased values, $47.5 \mathrm{~dB}$ (95\% CI, 45.9549.05), compared to the DM group (Figure 1(a)). DM mice presented delayed wave I-IV latencies compared to the normal group, from $2.79 \mathrm{~ms}$ ( $95 \% \mathrm{CI}, 2.77-2.81$ ) to $3.31 \mathrm{~ms}$
(95\% CI, 3.05-3.57). On the other hand, wave I-IV latencies of DM-DA group were similar to the normal group by $2.69 \mathrm{~ms}$ (95\% CI, 2.6-2.78) (Figure 1(b)).

AMLR Pa latencies in DM mice show slower values compared to the normal mice, $23.25 \mathrm{~ms}$ (95\% CI, 22.3$24.2)$ to $30.48 \mathrm{~ms}$ (95\% CI, 29.86-31.1). However, in DA9801 treated group (DM-DA), Pa latencies, $23.58 \mathrm{~ms}$ (95\% CI, 23.29-23.87), show faster values compared to the DM group (Figure 1(c)). After baseline comparison of ABR and AMLR within groups, no significant differences were found with the animal groups at the beginning of the study (data not shown). These data indicate that DA9801 suppresses the hearing threshold shifts and auditory pathway conduction delay in the diabetic mouse.

3.3. Nerve Growth Factor (NGF) Levels in Serum and Sciatic Nerves. In serum and sciatic nerves, NGF expressions of DM groups significantly reduced compared to the normal group. However, NGF ratios of DM-DA groups significantly increased (Figures 2(a) and 2(b)). These data show that DA9801 endogenously increased NGF level in serum and sciatic nerve. 


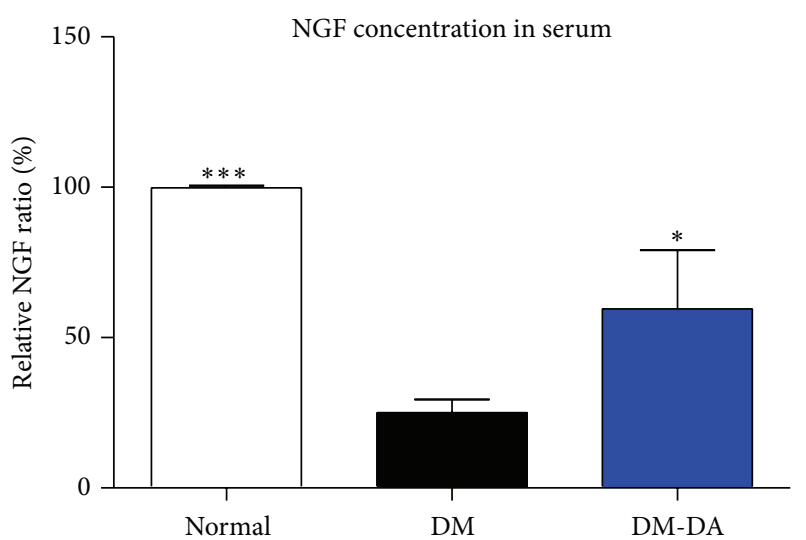

(a)

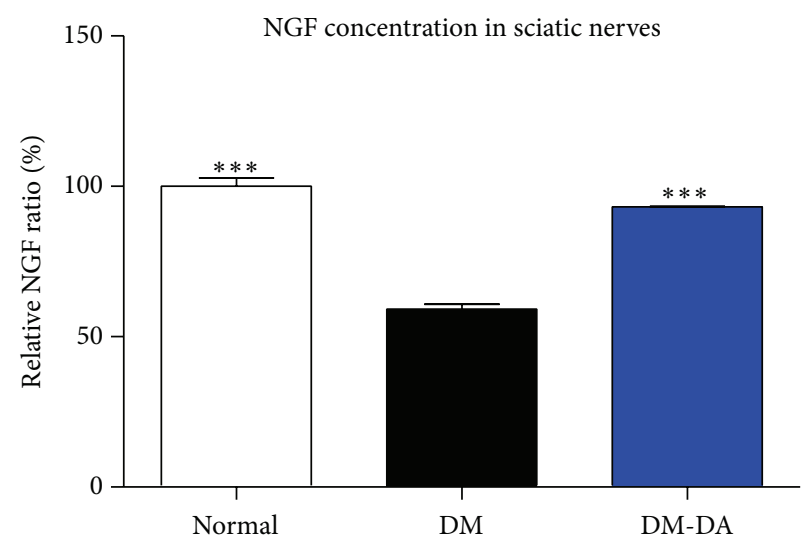

(b)

Figure 2: Nerve growth factor concentrations in serum and sciatic nerves. (a) Nerve growth factor relative ratio in serum and (b) sciatic nerves in normal, DM, and DM-DA groups. ${ }^{*} P<0.05$ and ${ }^{* * *} P<0.001$ indicate significant differences from DM group using one-way ANOVA.
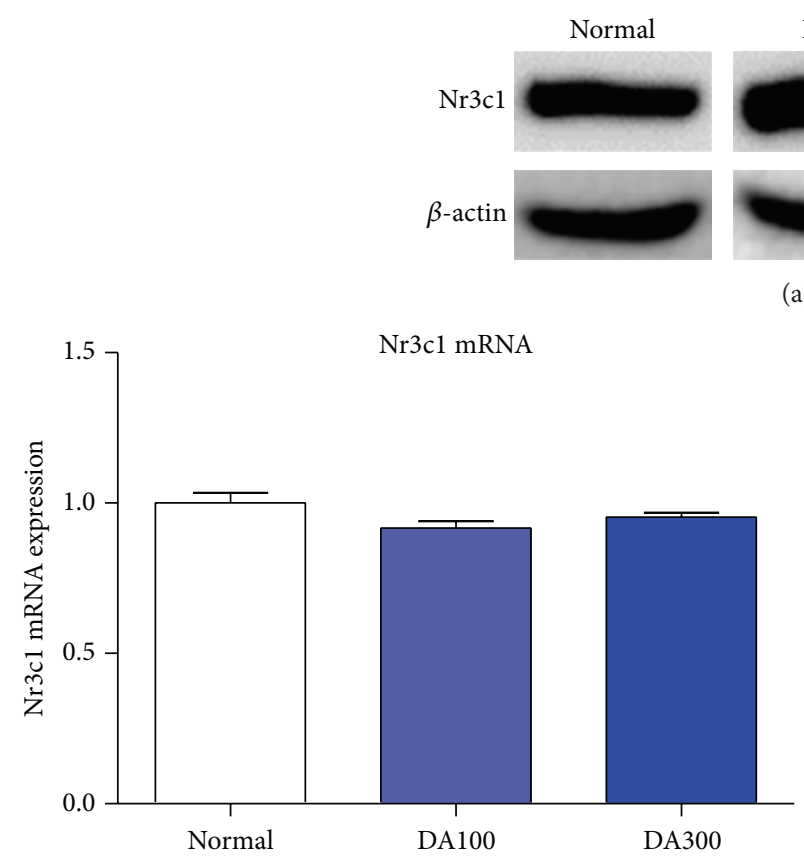

(b)

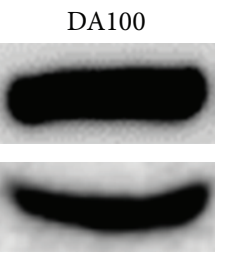

(a)

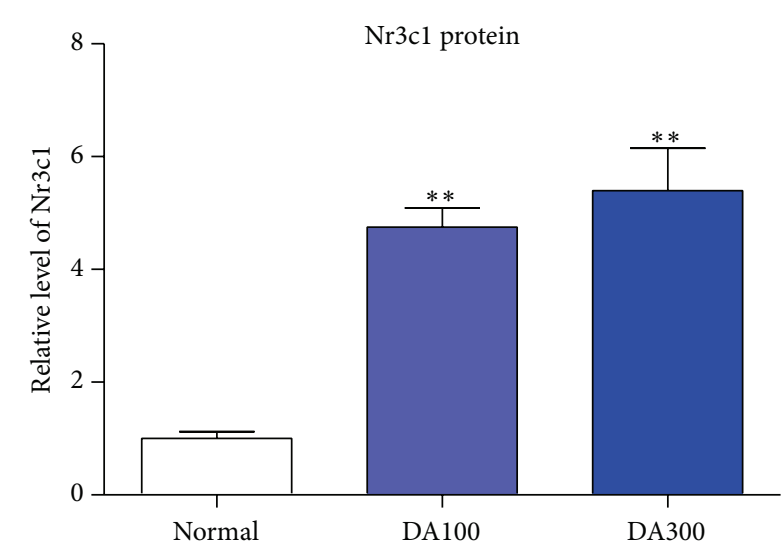

(c)

FIGURE 3: Nr3cl mRNA and protein expressions in liver. (a) Immunoblotting was performed on liver protein extracts using antibody of Nr3cl and $\beta$-actin which was used as constitutive control for normalization. (b) mRNA levels of Nr3cl in liver. (c) Relative protein expression levels of Nr3cl. Normal: nondiabetic mice model, DA100: nondiabetic mice model treated with DA9801 $100 \mathrm{mg} / \mathrm{kg}$, and DA300: nondiabetic mice model treated with DA9801 $300 \mathrm{mg} / \mathrm{kg}$. ${ }^{* *} P<0.01$ indicates significant differences from normal group using one-way ANOVA.

3.4. Nr3c1 Expression in Liver by DA9801. Nr3cl mRNA expression in the liver showed no change in normal, DA100, and DA300 groups (Figure 3(a)). Unlike mRNA, protein expression of $\mathrm{Nr} 3 \mathrm{cl}$ significantly increased in DA100 and DA300 group in a dose dependent manner (Figure 3(b)). Consequently, DA9801 elevates the systemic Nr3cl expression.

3.5. Tyrosine Kinase A (TrkA) mRNA Expression by DA9801. In DA100 and particularly DA300 group, TrkA levels showed increased expression in a dose dependent manner (Figure 4). These data indicate that DA9801 elevates the systemic TrkA expression.

3.6. DA9801 Aggrandize Cell Survival Signal. DA9801 increased p-Akt protein level and significantly changed in DA100 and DA300 groups (Figure 5). As a result, cell survival rate was increased by DA9801 through increased NGF level. 


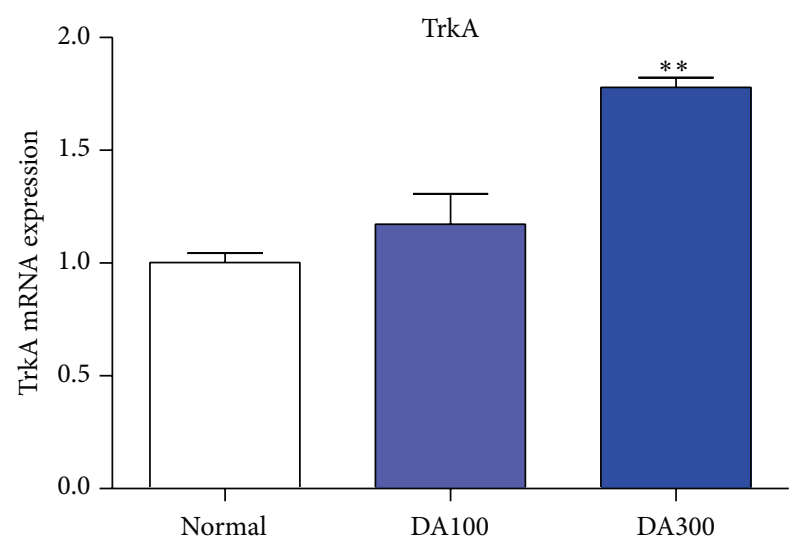

FIGURE 4: TrkA receptor expressions in liver. There is qPCR analysis of TrkA mRNA expressions in liver. ${ }^{* *} P<0.01$ indicates significant differences from normal group using one-way ANOVA.

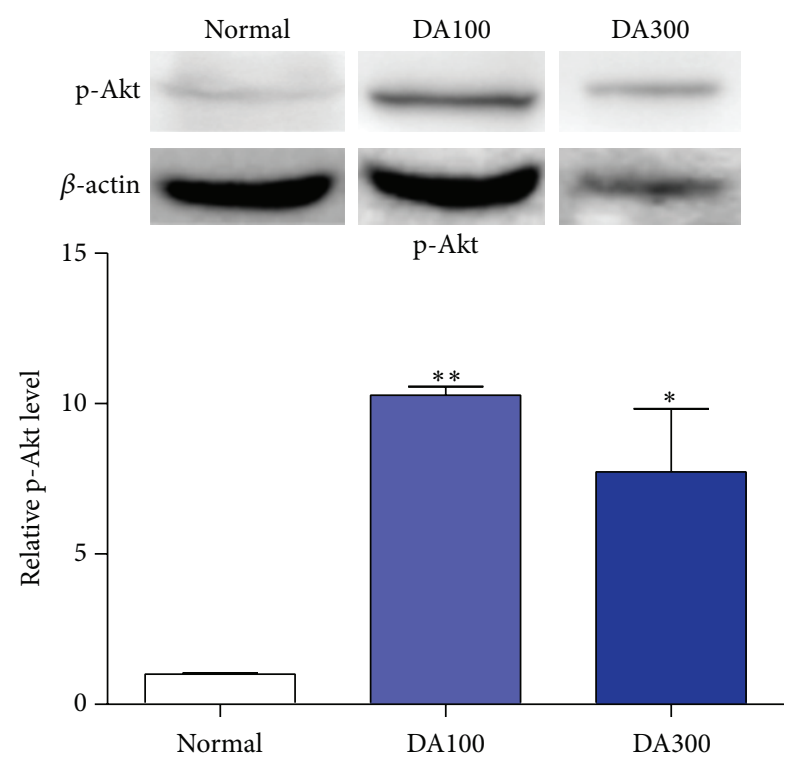

FIgURE 5: p-Akt level in liver. Immunoblotting proves p-Akt level in liver. $\beta$-actin is reference protein for normalization. Bar graph display normalization of immunoblotting. ${ }^{*} P<0.05$ and ${ }^{* *} P<0.01$ indicate significant differences from normal group using one-way ANOVA.

\section{Discussion}

DM may induce hearing impairment through loss of OHCs, spiral ganglion neuron atrophy [2-7], and decreased NGF levels $[38,39]$. Previous studies have used neurotrophin, such as a NGF injection method, for overcoming diabetic neuropathy $[36,37]$. A different approach based on endogenous NGF has been proposed by DA9801 extract and its mechanism needs to be addressed to understand its applications [41-44].

In this study, we investigated the effect of DA9801 on diabetic hearing impairment and mechanisms of induction of NGF through Nr3c1. This comprehensive study shows that increased ABR thresholds in response to clicks, having delayed ABR waves I-IV latencies and Pa latencies in AMLR, in the presence of auditory function being deteriorated by DM, could be a result of DA9801 treatment. Previous reports have shown that diabetic auditory dysfunction involves alterations in the auditory nerve and central auditory pathway, making electrophysiological tests, such as ABR and AMLR, useful tools for the evaluation of auditory impairments by measurement of hearing thresholds, latencies of waves I-IV, and $\mathrm{Pa}$ latency in STZ-induced diabetic animal models and human patients with diabetic neuropathy [8-10].

The ameliorative effects on auditory function shown by DA9801 were accompanied by the NGF release in serum and sciatic nerve. In previous studies, NGF levels have also shown increased value after DA9801 treatment [42], suggesting that this extract induces NGF release in nerves resulting in a physiological recovery and protection of the nerve. However, other mechanisms of DA9801 might be involved in the effects elicited by NGF. Many reports have shown signals related to NGF when it binds with the TrkA receptor such as phosphorylation that sends a signal downstream, and thus Akt transforms to phospho-Akt, resulting in increased cell survival [16-27]. Our results show that mRNA relative levels of TrkA were not changed among the 3 groups, and hence DA9801 has no effect on the transcript of TrkA receptor. However, DA9801 significantly increased phosphoAkt level. This partial relationship with NGF was confirmed with significantly increased $\mathrm{Nr} 3 \mathrm{cl}$ values in the liver after DA9801 treatment. These results suggest that the ameliorative effects of DA9801 showed in the auditory pathways might not involve TrkA receptor. Instead the mechanism of action might be related to elevated neuronal cell survival through elevating Nr3cl, Phospho-Akt, and NGF. In this regard, glucocorticoids have been widely used in the therapy of inner ear disease and acute noise-induced hearing loss [45] and since $\mathrm{Nr} 3 \mathrm{cl}$ is a glucocorticoid receptor found in rat, mouse, and human, even during development stage in mouse ears [4649], DA9801 might involve this valuable endogenous target. In addition, based on the chemical constituents of the extract, $\mathrm{Nr} 3 \mathrm{cl}$ was found as a biomarker candidate for correlation with NGF and DA9801 using an in silico method (data not shown). Therefore, we suggest that DA9801 ameliorates the auditory dysfunction produced by DM through $\mathrm{Nr} 3 \mathrm{cl}$ expression, and thus it induces NGF expression. However, since this study proved the systemic effect of DA9801 in part of the mechanism, further work is needed to investigate the effect on the auditory system and to explore the causal relationships between these biological markers.

\section{Conclusion}

The findings of this study show that recovery effect of DA9801 in the hearing impairment produced by DM model could be elicited by inducing NGF expression through $\mathrm{Nr} 3 \mathrm{cl}$ protein expression via Akt transformation.

\section{Conflict of Interests}

The authors have declared that there is no conflict of interests. 


\section{Authors' Contribution}

Yeong Ro Lee and Bin Na Hong contributed equally to this work.

\section{Acknowledgment}

This study was supported by the Basic Science Research Program through the National Research Foundation of Korea (NRF) funded by the Ministry of Science, ICT \& Future Planning (2012R1A1A2041525).

\section{References}

[1] C. Horikawa, S. Kodama, S. Tanaka et al., "Diabetes and risk of hearing impairment in adults: a meta-analysis," Journal of Clinical Endocrinology and Metabolism, vol. 98, no. 1, pp. 51-58, 2013.

[2] K. R. Rust, J. Prazma, R. J. Triana, O. E. Michaelis IV, and H. C. Pillsbury, "Inner ear damage secondary to diabetes mellitus: II. Changes in aging SHR/N-cp rats," Archives of OtolaryngologyHead and Neck Surgery, vol. 118, no. 4, pp. 397-400, 1992.

[3] E. Raynor, W. G. Robison, C. G. Garrett, W. T. Mcguirt, H. C. Pillsbury, and J. Prazma, "Consumption of a highgalactose diet induces diabetic-like changes in the inner ear," Otolaryngology - Head and Neck Surgery, vol. 113, no. 6, pp. 748754, 1995.

[4] E. M. Raynor, V. N. Carrasco, J. Prazma, and H. C. Pillsbury, "An assessment of cochlear hair-cell loss in insulin-dependent diabetes mellitus diabetic and noise-exposed rats," Archives of Otolaryngology - Head and Neck Surgery, vol.121, no. 4, pp. 452456, 1995.

[5] S. Nakae and M. Tachibana, "The cochlea of the spontaneously diabetic mice. II. Electron microscopic observations of nonobese diabetic mice," Archives of Oto-Rhino-Laryngology, vol. 243, no. 5, pp. 313-316, 1986.

[6] T. Ishikawa, Y. Naito, and K. Taniguchi, "Hearing impairment in WBN/Kob rats with spontaneous diabetes mellitus," Diabetologia, vol. 38, no. 6, pp. 649-655, 1995.

[7] H. Fukushima, S. Cureoglu, P. A. Schachern et al., "Cochlear change in patients with type 1 diabetes mellitus," Otolaryngology-Head and Neck Surgery, vol. 133, no. 1, pp. 100-106, 2005.

[8] R. J. McCrimmon, I. J. Deary, and B. M. Frier, "Auditory information processing during acute insulin-induced hypoglycaemia in non-diabetic human subjects," Neuropsychologia, vol. 35, no. 12, pp. 1547-1553, 1997.

[9] M. W. J. Strachan, F. M. E. Ewing, B. M. Frier, R. J. McCrimmon, and I. J. Deary, "Effects of acute hypoglycaemia on auditory information processing in adults with type I diabetes," Diabetologia, vol. 46, no. 1, pp. 97-105, 2003.

[10] G. K. Cooray, L. Maurex, and T. Brismar, "Cognitive impairment correlates to low auditory event-related potential amplitudes in type 1 diabetes," Psychoneuroendocrinology, vol. 33, no. 7, pp. 942-950, 2008.

[11] B. N. Hong and T. H. Kang, "Auditory neuropathy in streptozotocin-induced diabetic mouse," Neuroscience Letters, vol. 431, no. 3, pp. 268-272, 2008.

[12] M. Bibel and Y.-A. Barde, "Neurotrophins: key regulators of cell fate and cell shape in the vertebrate nervous system," Genes and Development, vol. 14, no. 23, pp. 2919-2937, 2000.
[13] E. J. de la Rosa and F. de Pablo, "Cell death in early neural development: beyond the neurotrophic theory," Trends in Neurosciences, vol. 23, no. 10, pp. 454-458, 2000.

[14] V. M. Verge, K. A. Gratto, L. A. Karchewski, and P. M. Richardson, "Neurotrophins and nerve injury in the adult," Philosophical Transactions of the Royal Society of London Series $B$, vol. 351, pp. 423-430, 1996.

[15] S. C. Apfel, J. A. Kessler, B. T. Adornato, W. J. Litchy, C. Sanders, and C. A. Rask, "Recombinant human nerve growth factor in the treatments of diabetic polyneuropathy," Neurology, vol. 51, no. 3, pp. 695-702, 1998.

[16] M. Bothwell, "Functional interactions of neurotrophins and neurotrophin receptors," Annual Review of Neuroscience, vol. 18, pp. 223-253, 1995.

[17] D. M. Loeb, R. M. Stephens, T. Copeland, D. R. Kaplan, and L. A. Greene, "A Trk nerve growth factor (NGF) receptor point mutation affecting interaction with phospholipase C-gammal abolishes NGF-promoted peripherin induction but not neurite outgrowth," The Journal of Biological Chemistry, vol. 269, no. 12, pp. 8901-8910, 1994.

[18] D. S. Middlemas, J. Meisenhelder, and T. Hunter, "Identification of TrkB autophosphorylation sites and evidence that phospholipase C-gamma 1 is a substrate of the TrkB receptor," The Journal of Biological Chemistry, vol. 269, no. 7, pp. 5458-5466, 1994.

[19] R. M. Stephens, D. M. Loeb, T. D. Copeland, T. Pawson, L. A. Greene, and D. R. Kaplan, "Trk receptors use redundant signal transduction pathways involving SHC and PLC- $\gamma 1$ to mediate NGF responses," Neuron, vol. 12, no. 3, pp. 691-705, 1994.

[20] L. A. Greene and D. R. Kaplan, "Early events in neurotrophin signalling via Trk and p75 receptors," Current Opinion in Neurobiology, vol. 5, no. 5, pp. 579-587, 1995.

[21] D. R. Alessi, F. B. Caudwell, M. Andjelkovic, B. A. Hemmings, and P. Cohen, "Molecular basis for the substrate specificity of protein kinase B; comparison with MAPKAP kinase-1 and p70 S6 kinase," FEBS Letters, vol. 399, no. 3, pp. 333-338, 1996.

[22] M. Andjelković, T. Jakubowicz, P. Cron, X.-F. Ming, J.-W. Han, and B. A. Hemmings, "Activation and phosphorylation of a pleckstrin homology domain containing protein kinase (RAC-PK/PKB) promoted by serum and protein phosphatase inhibitors," Proceedings of the National Academy of Sciences of the United States of America, vol. 93, no. 12, pp. 5699-5704, 1996.

[23] B. M. Burgering and P. J. Coffer, "Protein kinase B (c-Akt) in phosphatidylinositol-3-OH kinase signal transduction," Nature, vol. 376, no. 6541, pp. 599-602, 1995.

[24] T. F. Franke, D. R. Kaplan, and L. C. Cantley, "PI3K: Downstream AKTion blocks apoptosis," Cell, vol. 88, no. 4, pp. 435437, 1997.

[25] A. Klippel, W. M. Kavanaugh, D. Pot, and L. T. Williams, "A specific product of phosphatidylinositol 3-kinase directly activates the protein kinase Akt through its pleckstrin homology domain," Molecular and Cellular Biology, vol. 17, no. 1, pp. 338344, 1997.

[26] S. R. Datta, H. Dudek, T. Xu et al., "Akt phosphorylation of BAD couples survival signals to the cell-intrinsic death machinery," Cell, vol. 91, no. 2, pp. 231-241, 1997.

[27] L. del Peso, M. González-García, C. Page, R. Herrera, and G. Nuñez, "Interleukin-3-induced phosphorylation of BAD through the protein kinase Akt," Science, vol. 278, no. 5338, pp. 687-689, 1997.

[28] I. Mocchetti, G. Spiga, V. Y. Hayes, P. J. Isackson, and A. Colangelo, "Glucocorticoids differentially increase nerve growth factor and basic fibroblast growth factor expression in the rat 
brain," The Journal of Neuroscience, vol. 16, no. 6, pp. 2141-2148, 1996.

[29] G. Barbany and H. Persson, "Regulation of neurotrophin mRNA expression in the rat brain by glucocorticoids," European Journal of Neuroscience, vol. 4, no. 5, pp. 396-403, 1992.

[30] F. Tronche, C. Kellendonk, H. M. Reichardt, and G. Schütz, "Genetic dissection of glucocorticoid receptor function in mice," Current Opinion in Genetics and Development, vol. 8, no. 5, pp. 532-538, 1998.

[31] A. Abdallat, S. M. Davis, J. Farrage, and W. I. McDonald, "Disordered pigmentation, spastic paraparesis and peripheral neuropathy in three siblings: a new neurocutaneous syndrome," Journal of Neurology, Neurosurgery \& Psychiatry, vol. 43, no. 11, pp. 962-966, 1980.

[32] Y. Bayazit, M. Yilmaz, Y. Kepekçi, S. Mumbuç, and M. Kanlikama, "Use of the auditory brainstem response testing in the clinical evaluation of the patients with diabetes mellitus," Journal of the Neurological Sciences, vol. 181, no. 1-2, pp. 29-32, 2000.

[33] L. V. D. de León-Morales, K. Jáuregui-Renaud, M. E. GaraySevilla, J. Hernández-Prado, and J. M. Malacara-Hernández, "Auditory impairment in patients with type 2 diabetes mellitus," Archives of Medical Research, vol. 36, no. 5, pp. 507-510, 2005.

[34] K. E. Rarey, L. M. Curtis, and W. J.-F. T. Cate, "Tissue specific levels of glucocorticoid receptor within the rat inner ear," Hearing Research, vol. 64, no. 2, pp. 205-210, 1993.

[35] R. D. Glick, I. Medary, D. C. Aronson, K. W. Scotto, S. L. Swendeman, and M. P. La Quaglia, "The effects of serum depletion and dexamethasone on growth and differentiation of human neuroblastoma cell lines," Journal of Pediatric Surgery, vol. 35, no. 3, pp. 465-472, 2000.

[36] S. C. Apfel, J. C. Arezzo, M. Brownlee, H. Federoff, and J. A. Kessler, "Nerve growth factor administration protects against experimental diabetic sensory neuropathy," Brain Research, vol. 634, no. 1, pp. 7-12, 1994.

[37] P. Fernyhough, L. T. Diemel, J. Hardy, W. J. Brewster, L. Mohiuddin, and D. R. Tomlinson, "Human recombinant nerve growth factor replaces deficient neurotrophic support in the diabetic rat," European Journal of Neuroscience, vol. 7, no. 5, pp. 1107-1110, 1995.

[38] B. C. Steinbacher Jr. and I. Nadelhaft, "Increased levels of nerve growth factor in the urinary bladder and hypertrophy of dorsal root ganglion neurons in the diabetic rat," Brain Research, vol. 782, no. 1-2, pp. 255-260, 1998.

[39] R. Hellweg, M. Wohrle, H.-D. Hartung, H. Stracke, C. Hock, and K. Federlin, "Diabetes mellitus-associated decrease in nerve growth factor levels is reversed by allogenic pancreatic islet transplantation," Neuroscience Letters, vol. 125, no. 1, pp. 1-4, 1991.

[40] P. Bernd and J. Represa, "Characterization and localization of nerve growth factor receptors in the embryonic otic vesicle and cochleovestibular ganglion," Developmental Biology, vol. 134, no. 1, pp. 11-20, 1989.

[41] S.-Z. Choi and M.-W. Son, "Novel botanical drug for the treatment of diabetic neuropathy," Archives of Pharmacal Research, vol. 34, no. 6, pp. 865-867, 2011.

[42] N. Kim, S.-H. Kim, Y.-J. Kim et al., "Neurotrophic activity of DA-9801, a mixture extract of Dioscorea japonica Thunb. and Dioscorea nipponica Makino, in vitro," Journal of Ethnopharmacology, vol. 137, no. 1, pp. 312-319, 2011.

[43] H. Y. Jin, S. H. Kim, H. M. Yu, H. S. Baek, and T. S. Park, "Therapeutic potential of Dioscorea extract (DA-9801) in comparison with alpha lipoic acid on the peripheral nerves in experimental diabetes," Journal of Diabetes Research, vol. 2013, Article ID 631218, 10 pages, 2013.

[44] K. A. Lee, H. Y. Jin, H. S. Baek, and T. S. Park, “The protective effects of DA-9801 (Dioscorea Extract) on the peripheral nerves in streptozotocin-induced diabetic rats," Journal of Nutritional Science and Vitaminology, vol. 59, no. 5, pp. 437-446, 2013.

[45] K. J. Livak and T. D. Schmittgen, "Analysis of relative gene expression data using real-time quantitative PCR and the $2^{-\triangle \Delta C T}$ method," Methods, vol. 25, no. 4, pp. 402-408, 2001.

[46] T. Tsuiki, K. Ando, and K. M. Jun, "Treatment of acute hearing loss due to acoustic trauma," Journal of Otolaryngology of Japan, vol. 84, no. 7, pp. 740-748, 1981.

[47] W.-J. F. T. Cate, L. M. Curtis, G. M. Small, and K. E. Rarey, "Localization of glucocorticoid receptors and glucocorticoid receptor mRNAs in the rat cochlea," Laryngoscope, vol. 103, no. 8, pp. 865-871, 1993.

[48] S. Erichsen, D. Bagger-Sjöbäck, L. Curtis, J. Zuo, K. Rarey, and M. Hultcrantz, "Appearance of glucocorticoid receptors in the inner ear of the mouse during development," Acta OtoLaryngologica (Stockh.), vol. 116, no. 5, pp. 721-725, 1996.

[49] K. E. Rarey and L. M. Curtis, "Receptors for glucocorticoids in the human inner ear," Otolaryngology-Head and Neck Surgery, vol. 115, no. 1, pp. 38-41, 1996. 


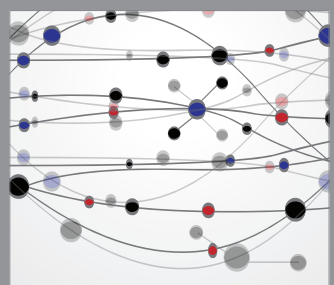

The Scientific World Journal
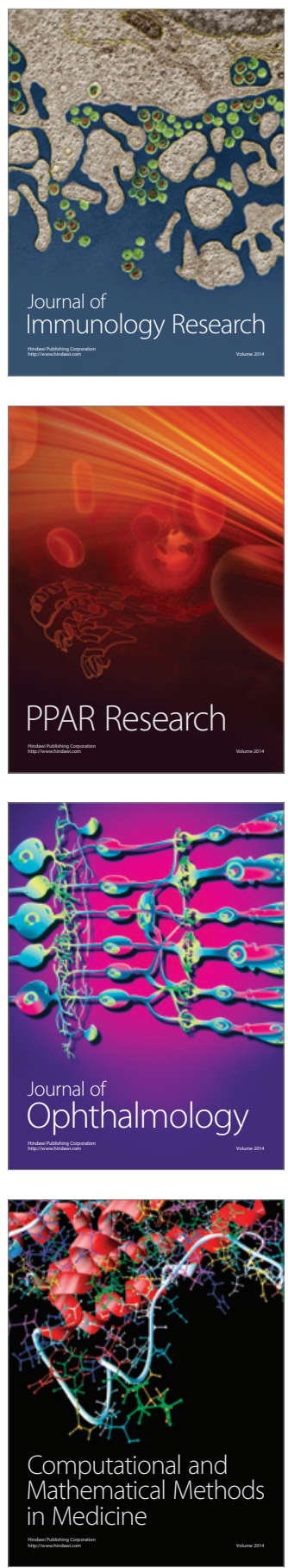

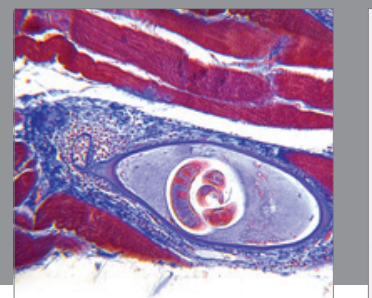

Gastroenterology

Research and Practice
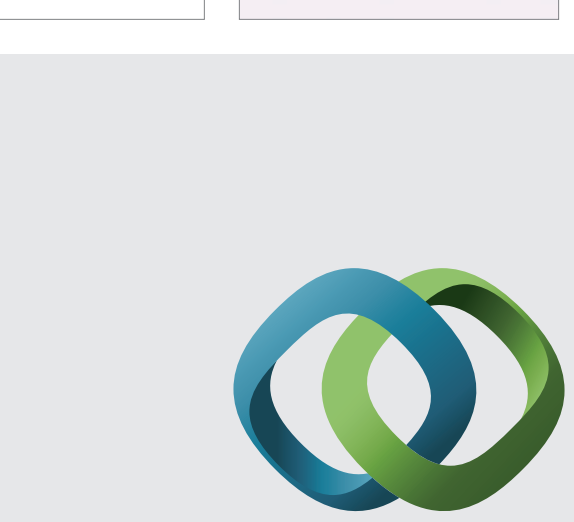

\section{Hindawi}

Submit your manuscripts at

http://www.hindawi.com
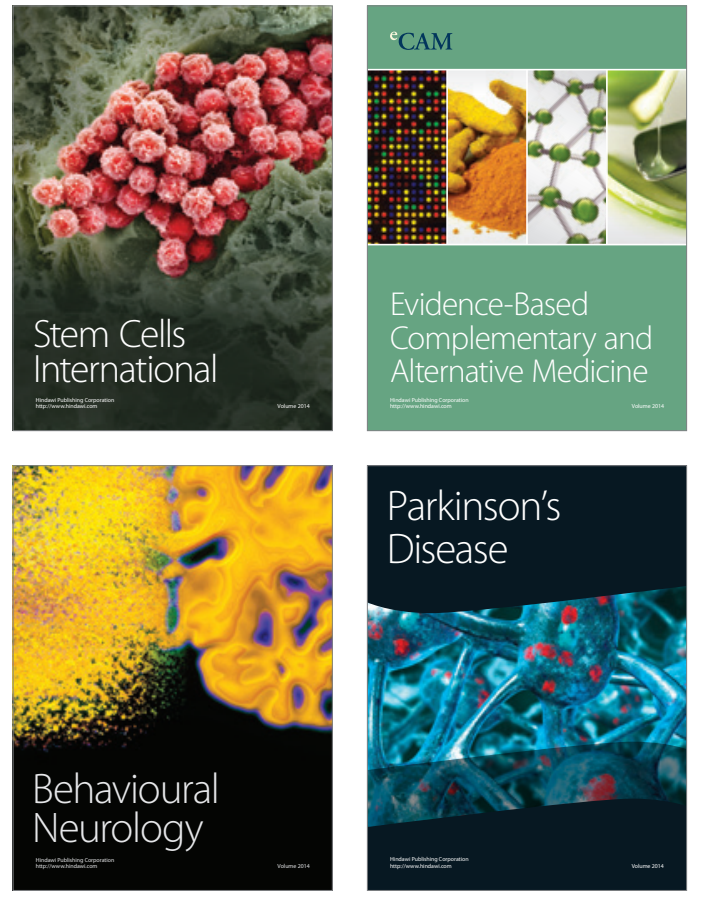
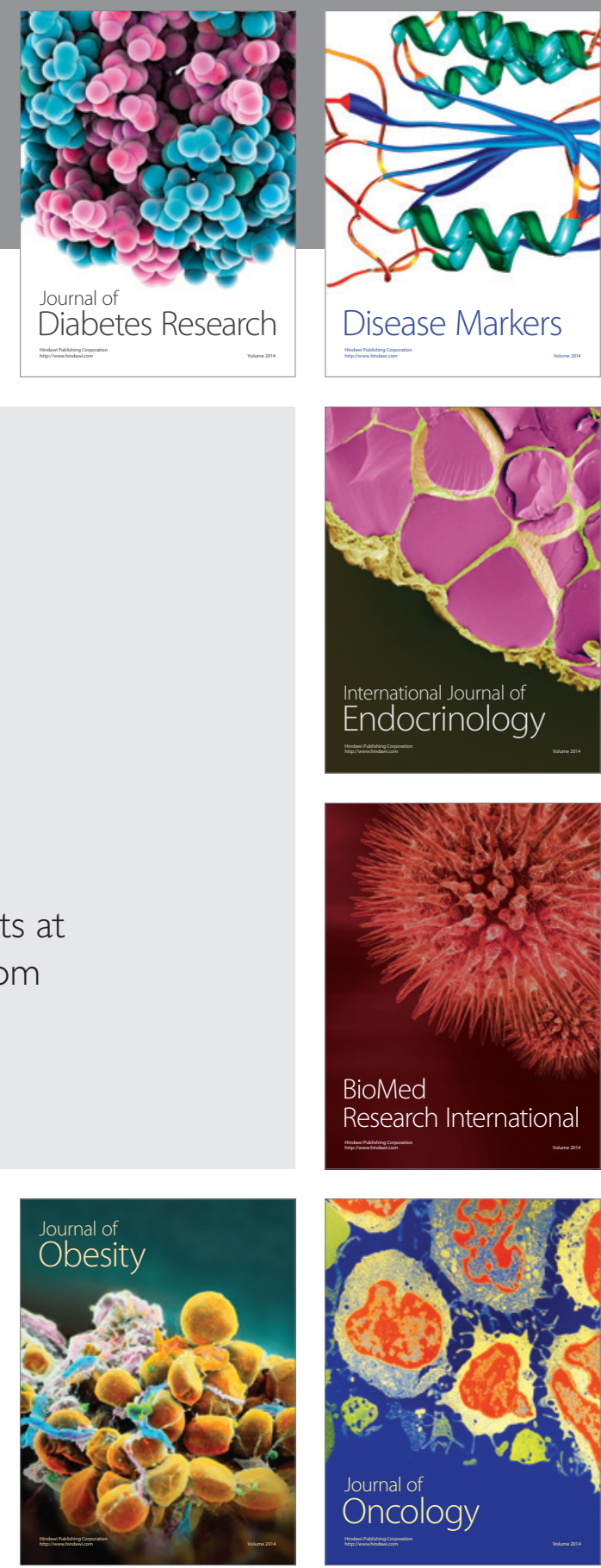

Disease Markers
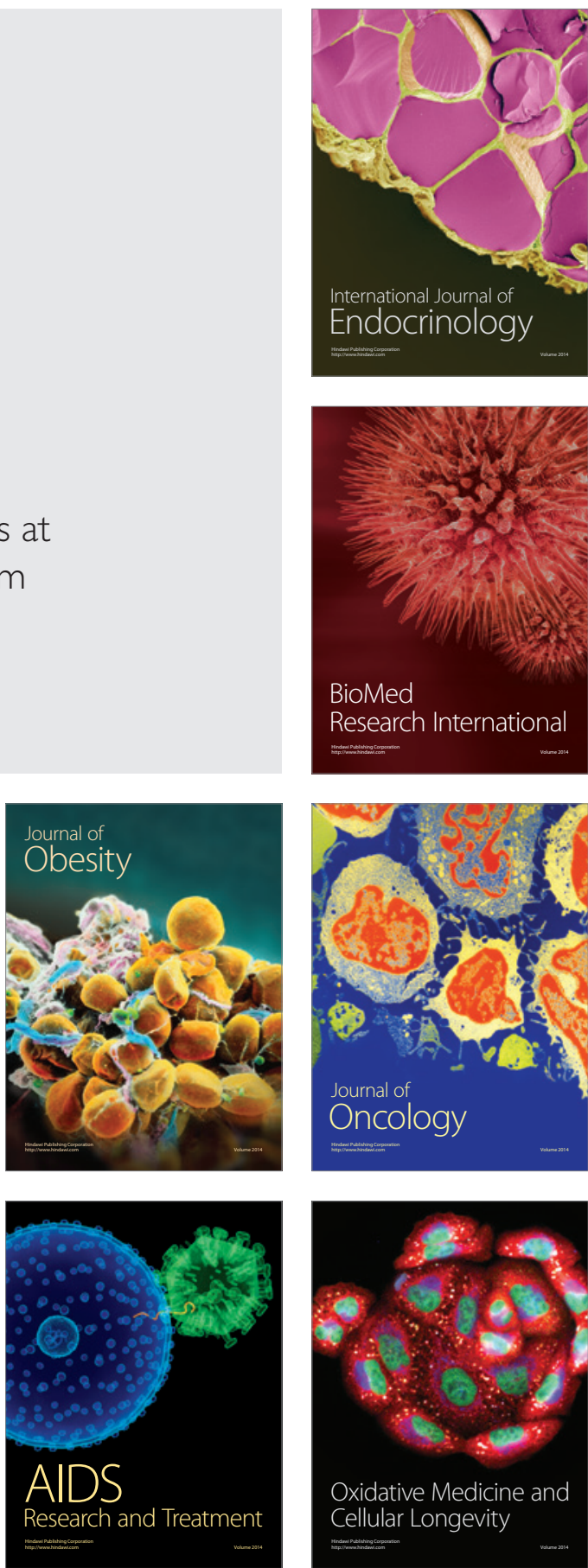